\title{
APLIKASI ASAP CAIR UNTUK MENGURANGI KADAR LOGAM BERAT DAN TOTAL BAKTERI PADA KERANG HIJAU (PERNA VIRIDIS)
}

\author{
Nevia Cahyani Mujiyanto ${ }^{\mathrm{a}}$, Muhammad Adam WIldan ${ }^{\mathrm{a}}$, Naufal Aufa Elian ${ }^{\mathrm{a}}$, \\ Retno Ayu Kurrniasih ${ }^{\text {a* }}$ \\ ${ }^{a}$ Departemen Teknologi Hasil Perikanan, Fakultas Perikanan dan Ilmu Kelautan, Universitas Diponegoro, Jl. \\ Prof. H. Soedarto S.H., Tembalang, Kec. Tembalang, Kota Semarang, Jawa Tengah 50275, Indonesia \\ *Koresponden penulis : retnoayukurniasih@lecturer.undip.ac.id
}

\begin{abstract}
Abstrak
Kerang hijau mampu bertahan hidup di perairan tercemar, sehingga daging kerang hijau dapat terkontaminasi baik logam berat maupun bakteri. Oleh karena itu, diperlukan suatu teknologi untuk mereduksi logam berat dan bakteri untuk meningkatkan mutu dan keamanan pangan daging kerang hijau. Salah satu teknologi yang dapat diterapkan adalah perendaman daging kerang dalam asap cair. Senyawa fenol, karbonil, dan asam organik yang terkandung dalam asap cair dapat berfungsi mereduksi logam berat dan sebagai antibakteri. Penelitian ini bertujuan untuk mengevaluasi efektifitas jenis asap cair berbeda (bonggol jagung, tempurung kelapa, dan sekam padi) terhadap kadar logam berat (Cadmium dan Cuprum) dan total bakteri serta pengaruh perendaman asap cair terhadap kadar proksimat dan nilai organoleptik daging kerang hijau. Larutan asap cair 10\% (v/v) dengan rasio 1:1 (b/v) digunakan untuk merendam daging kerang hijau selama 30 menit selanjutnya dilakukan pencucian. Hasil penelitian menunjukkan bahwa perendaman asap cair dapat mereduksi kadar Cadmium sebesar 14,58\%, kadar Cuprum sebesar 46,29\%, dan total bakteri sebesar 34,57 s.d. 50,57\% pada daging kerang hijau. Perendaman asap cair tempurung kelapa menyebabkan daging kerang hijau memiliki kadar air terendah dan kadar protein tertinggi. Namun, perendaman asap cair juga menyebabkan penurunan nilai organoleptik terhadap rasa daging kerang hijau.
\end{abstract}

Kata Kunci: asap cair, kerang hijau, logam berat; total bakteri

\begin{abstract}
Green mussel can survive in polluted waters, so that green mussel can be contaminated with heavy metals and bacteria. Therefore, a technology is needed to reduce heavy metals and bacteria to improve the quality and food safety of green mussel. One of the technologies that can be applied is soaking green mussel in liquid smoke. Phenol, carbonyl, and organic acid compounds in liquid smoke can function as a chelating agent of heavy metal and as an antibacterial. The aimed of this study was to evaluate the effectiveness of different types of liquid smoke (corncob, coconut shell, and rice husk) on the content of heavy metals (Cadmium and Cuprum) and total bacteria as well as the effect of soaking liquid smoke on the proximate and organoleptic values of green mussels. A liquid smoke solution of $10 \%(\mathrm{v} / \mathrm{v})$ at a ratio of 1:1 (w/v) was used to soak the green mussels for 30 min after which washing was carried out. The results showed that soaked in liquid smoke could reduce Cadmium content by $14.58 \%$, Cuprum content by $46.29 \%$, and total bacteria 34.57 to $50.57 \%$ of green mussel. Soaked of coconut shell liquid smoke causes green mussel to have the lowest moisture content and the highest protein content. However, soaked in liquid smoke also causes a decrease in the organolepctic value of the taste of green mussels.
\end{abstract}

Keywords: green mussle, heavy metals, liquid smoke, total bacteria.

\section{PENDAHULUAN}

Salah satu sumberdaya laut golongan Bivalvia yang memiliki potensi sebagai salah satu sumber makanan oleh masyarakat di Indonesia adalah kerang hijau (Perna viridis). Jika dibandingkan dengan biota laut lainnya, kerang lebih resisten terhadap kondisi perairan yang terkontaminasi logam berat dan bakteri dari limbah industri maupun rumah tangga. Hal inilah yang menyebabkan jumlahnya berlimpah. Selain mengandung protein dan lemak, kerang hijau juga mengandung vitamin (A dan B12) serta 
mineral (fosfor, kalium, kalsium, dan besi) [1].

Pada sisi lain, kemampuan kerang untuk bertahan hidup pada perairan tercemar dapat mengakibatkan akumulasi logam berat dan bakteri pada daging, sehingga menyebabkan daging kerang tidak aman dikonsumsi oleh manusia. Daging kerang dapat mengandung logam berat melebihi berat tubuhnya. Adanya bakteri dan logam berat dalam jumlah banyak pada bahan makanan, dapat mengakibatkan keracunan pada manusia yang mengonsumsinya. Logam berat juga dapat memberikan efek toksik pada manusia dengan konsentrasi terendah dalam jangka waktu yang lama [2].

Logam berat dan bakteri yang terakumulasi dalam kerang hijau dapat direduksi dengan menggunakan senyawa asam, misalnya asam asetat $[3,4,5]$. Namun penggunaan senyawa asam yang terlalu tinggi dapat menyebabkan tekstur daging kerang hijau mangalami kerusakan dan menjadi lebih keras akibat dari terkoagulasinya protein kerang hijau. Solusi yang dapat dilakukan untuk mengurangi kandungan kontaminasi logam berat dan bakteri pada kerang hijau adalah dengan menggunakan asap cair, yaitu hasil pirolisis bahan yang mengandung selulosa, hemiselulosa, dan lignin.

Senyawa fenol, karbonil, dan asam dalam asap cair dapat berfungsi sebagai chelating agent (bahan pengkhelat) logam berat, sehingga dapat menurunkan logam berat pada kedelai [6]. Swastawati et al. [7] juga telah melakukan penelitian bahwa asap cair tempurung kelapa efektif menurunkan total bakteri dan meningkatkan nilai sensori ikan cakalang. Asap cair telah banyak dimanfaatkan sebagai pewarna, perasa, antibakteri, dan antioksidan [8, 9], tetapi belum ada informasi mengenai aplikasi asap cair untuk meningkatkan keamanan pangan daging kerang. Oleh karena itu, penelitian ini bertujuan untuk mengevaluasi efektifitas jenis asap cair yang berbeda (bonggol jagung, tempurung kelapa, dan sekam padi) terhadap kadar logam berat Cadmium (Cd) dan Cuprum $(\mathrm{Cu})$ serta total koliform dan total bakteri pada daging kerang hijau. Tujuan lain dalam penelitian ini adalah mengetahui kadar proksimat dan nilai organoleptik daging kerang hijau yang direndam dalam asap cair.

\section{METODE}

\section{Bahan dan Alat}

Bahan yang digunakan adalah kerang hijau (Perna viridis), asap cair (jenis tempurung kelapa, sekam padi, dan bonggol jagung) (PT Asap Cair Multiguna, Indonesia), serta aquades merupakan bahan-bahan yang digunakan dalam penelitian ini. Kerang hijau didapatkan dari Pasar Rejo Mulyo, Semarang, Jawa Tengah. Ada pun bahan kimia yang digunakan pada pengujian produk meliputi larutan standar $\mathrm{Pb}\left(\mathrm{NO}_{3}\right)_{2} 1000 \mathrm{mg} / \mathrm{L}, \mathrm{HNO}_{3}$, $\mathrm{HCl}$, asam asetat, asam oksalat, asam nitrat, asam perklorat, aquades, 2,4-dinitrophenyl hydrazine, $\mathrm{KOH}, \mathrm{Na}_{2} \mathrm{CO}_{3}$, lactose broth, phenolptalein, dan Folin-ciocalteau. Seluruh bahan kimia yang digunakan merupakan produksi dari Merck, Jerman.

Alat yang digunakan adalah Spektrofotometer UV-VIS (Shimadzu UV1280, Jepang), vortex (Wizard, Velp Scientifica, Itali), inkubator (MIR-262, Sanyo, Jepang), mikropipet (SVA-600, Accumax Smart, Inggris), colony counter (Stuart Scientific, Inggris), dan AAS (Atomic Absorption Spectrophotometer) (Flame AA7000 Series, Smimadzu Corporation, Jepang) merupakan alat-alat yang digunakan dalam penelitian ini.

\section{Perendaman Daging Kerang Hijau dalam Asap Cair}

Sampel kerang hijau direbus $\left(100{ }^{\circ} \mathrm{C}, 10\right.$ menit) hingga cangkang terbuka. Selanjutnya daging kerang dipisahkan dari cangkangnya. Daging kerang direndam pada larutan asap cair (bonggol jagung, tempurung kelapa, sekam padi) $10 \%(\mathrm{v} / \mathrm{v})$ selama 30 menit dengan rasio 1:1 (b/v). Setelah daging kerang dicuci dengan menggunakan aquades dan ditiriskan, dilakukan pengujian kadar logam berat, bakteri, kadar proksimat, dan organoleptik. Pada penelitian ini juga dilakukan pengujian daging kerang tanpa 
perlakuan perendaman dalam asap cair sebagai control.

\section{Karakterisasi Asap Cair}

Asap cair (jenis bonggol jagung, tempurung kelapa, dan sekam padi) dikarakterisasi kadar fenol, kadar karbonil, dan total asam. Pengujian kadar fenol dilakukan dengan mengencerkan $5 \mathrm{~g}$ sampel dalam $100 \mathrm{ml}$ aquades kemudian disaring. Larutan sampel $(0,5 \mathrm{ml})$ ditambah $1 \mathrm{ml}$ larutan $\mathrm{Na}_{2} \mathrm{CO}_{3}$ jenuh dan $0,5 \mathrm{ml}$ reagen follin denis kemudian didiamkan selama 3 menit. Larutan ditambahkan aquades sampai $10 \mathrm{ml}$ dan divortex hingga homogen. Absorbansi dibaca dengan spektrofotometer dengan panjang gelombang $730 \mathrm{~nm}$ [10].

Pengujian kadar karbonil diawali dengan mengambil sampel sebanyak 5 g kemudian diencerkan menggunakan aquades sehingga diperoleh faktor pengenceran 400x. Larutan sampel sebanyak $1 \mathrm{ml}$ ditambah dengan $50 \mu \mathrm{l}$ $\mathrm{HCl}$ pekat dan $1 \mathrm{ml}$ 2,4-dinitrophenyl hydrazine $\left(50 \quad{ }^{\circ} \mathrm{C}, \quad 30\right.$ menit $)$. Setelah didinginkan, $8 \mathrm{ml}$ larutan $\mathrm{KOH} \quad 1 \quad \mathrm{~N}$ ditambakan dalam larutan. Selanjutnya larutan sampel diabsorbansi menggunakan spektrofotometer pada $480 \mathrm{~nm}$ [6].

Pengujian total asam penggunakan metode titrasi, yaitu sampel $\left(\begin{array}{lll}1 & \mathrm{ml}\end{array}\right)$ ditambahkan $100 \mathrm{~mL}$ aquades dan phenolptalein $1 \%$ kemudian dititrasi dengan menggunakan $\mathrm{NaOH} 0,1 \mathrm{~N}$ hingga berwarna merah muda [11]. Kadar total asam dapat dihitung dengan persamaan (1).

$$
\text { Total Asam }(\%)=\frac{V \times N \text { x BM x F p x } 100 \%}{\text { mg sampel }}
$$

Keterangan :

$$
\begin{array}{ll}
\mathrm{V} & : \text { Volume } \mathrm{NaOH}(\mathrm{ml}) \\
\mathrm{N} & : \text { Normalitas larutan } \mathrm{NaOH} \\
\mathrm{BM} & : \text { Berat molekul asam asetat } \\
\mathrm{Fp} & : \text { Faktor pengenceran }(100 \mathrm{x})
\end{array}
$$

\section{Kadar Cd dan $\mathrm{Cu}$}

Daging kerang hijau (500 mg ditambahkan $1 \mathrm{~mL}$ asam nitrat dan asam perklorat serta 2,5 $\mathrm{mL}$ aquades untuk mengekstraksi logam berat pada sampel. Selanjutnya filtrat diabsorbansi menggunakan AAS. Metode ini bekerja dengan membandingkan absorbansi larutan sampel dengan larutan standar untuk mendapatkan konsentrasi $\mathrm{Cd}$ dan $\mathrm{Cu}$ pada sampel [5].

\section{Uji Koliform}

Penentuan jumlah bakteri koliform dilakukan dengan metode Most Probable Number (MPN) yang mengacu pada Askar et al. [12]. Tabung Lactose Broth yang menunjukkan hasil positif, diambil satu ose kemudian dimasukkan kedalam tabung Brilliant Lactose Broth (BLB). Sampel diinkubasi pada suhu $37{ }^{\circ} \mathrm{C}$ selama 24 jam. Hasil jumlah bakteri koliform dicocokkan dengan tabel perhitungan MPN.

\section{Total Bakteri}

Sampel (1 g) dilarutkan dalam larutan $\mathrm{NaCl}$ fisiologis hingga faktor pengenceran $10^{-}$ ${ }^{1}, 10^{-2}$, dan $10^{-3}$. Larutan sampel sebanyak 0,1 $\mathrm{mL}$ untuk setiap faktor pengenceran dituang ke dalam cawan berisi nutrien agar kemudian diinkubasi pada suhu ruang $25-27{ }^{\circ} \mathrm{C}$ selama 24 jam. Setelah dinkubasi, koloni mikroba yang tumbuh dihitung dan dikalikan dengan faktor pengenceran [13].

\section{Kadar Proksimat}

Perhitungan kadar air menggunakan metode pengeringan, dihitung berdasarkan kehilangan massa yakni selisih dari massa awal dengan massa akhir. Kadar protein adalah dengan mengukur protein kasar yang berfungsi untuk mengetahui jumlah protein total yang terdapat pada sampel, metode pengukuran protein dengan metode kjeldahl. Kadar lemak menggunakan metode soxlet. Kadar abu diketaui dengan menghitung massa dari mineral hasil pembakaran secara langsung pada suhu $600{ }^{\circ} \mathrm{C}$ selama 6 jam [13].

\section{Uji Organoleptik}

Uji organoleptik dilakukan untuk menilai mutu daging kerang dengan menggunakan 
panca indera berdasarkan schore sheet organoleptik daging kerang beku (setelah thawing) No. 01-2346-2006 oleh 25 orang panelis berusia antara 20 sampai 25 tahun [15].

\section{Analisis Data}

Data parametrik (kadar $\mathrm{Cd}$, kadar $\mathrm{Cu}$, dan kadar proksimat) yang merupakan ratarata dari 3 kali ulangan \pm standar deviasi dianalisis sidik ragam kemudian uji Duncan untuk melihat perbedaan antarperlakuan $(\mathrm{p}<$ 0,05). Data non parametrik (organoleptik) dianalisa menggunakan Kruskal-wallis dilanjutkan uji Man-Whitney untuk mengetahui pengaruh setiap perlakuan. SPSS versi 17 (International Business Machines Corporation, USA) merupakan aplikasi yang digunakan dalam olah data pada penelitian ini.

\section{HASIL DAN PEMBAHASAN}

\section{Karakteristik Asap Cair}

Pengujian karakteristik asap cair dilakukan pengujian secara kimia yang meliputi kadar fenol, kadar karbonil, dan total asam. Hasil pengujian menunjukkan bahwa perbedaan bahan baku dalam pembuatan asap cair dapat mempengaruhi kadar fenol, kadar karbonil, dan total asam (Tabel 1). Hartati et al. [6] menyatakan bahwa jenis dan varietas bahan yang digunakan dapat mempengaruhi kandungan senyawa asap cair. Lignin yang terkandung dalam bahan akan diubah menjadi fenol pada suhu 300 s.d. $450{ }^{\circ} \mathrm{C}$. Selama pirolisa, selulosa akan diubah menjadi senyawa karbonil dan asam. Senyawa asam yang utama dalam asap cair adala asam asetat.

Tabel 1. Karakteristik Asap Cair

\begin{tabular}{cccc}
\hline Asap Cair & $\begin{array}{c}\text { Kadar } \\
\text { Fenol } \\
(\%)\end{array}$ & $\begin{array}{c}\text { Kadar } \\
\text { Karbonil } \\
(\%)\end{array}$ & $\begin{array}{c}\text { Total } \\
\text { Asam } \\
(\%)\end{array}$ \\
\hline $\begin{array}{c}\text { Bonggol } \\
\text { Jagung }\end{array}$ & 1,95 & 0,55 & 17,75 \\
$\begin{array}{c}\text { Tempurung } \\
\text { Kelapa }\end{array}$ & 1,02 & 0,03 & 10,75 \\
$\begin{array}{c}\text { Sekam } \\
\text { Padi }\end{array}$ & 2,87 & 1,09 & 23,44 \\
\hline
\end{tabular}

\section{Kadar Cd}

Hasil pengujian kadar Cd daging kerang hijau berkisar antara 0,041 s.d. $0,048 \mathrm{mg} / \mathrm{kg}$. Berdasarkan SNI No. 7387:2009, maka seluruh sampel kerang telah memenuhi persyaratan mutu dan keamanan pangan daging kerang, yaitu tidak lebih dari $1 \mathrm{mg} / \mathrm{kg}$ [16]. Meskipun kadar Cd belum melampaui batas yang diizinkan, kandungan $\mathrm{Cd}$ dalam daging kerang hijau harus dikurangi karena dapat menyebabkan $\mathrm{Cd}$ terakumulasi dalam tubuh ketika dikonsumsi. Cd dalam tubuh dapat berperan sebagai allergen, mutagen, dan karsinogenik [17].

Tabel 2. Kadar $\mathrm{Cd}$ dan $\mathrm{Cu}$ pada Daging Kerang Hijau

\begin{tabular}{ccc}
\hline Perlakuan & $\begin{array}{c}\text { Kadar Cd } \\
(\mathrm{mg} / \mathrm{kg})\end{array}$ & $\begin{array}{c}\text { Kadar Cu } \\
(\mathrm{mg} / \mathrm{kg})\end{array}$ \\
\hline $\begin{array}{c}\text { Kontrol } \\
\text { Bonggol }\end{array}$ & $0,048 \pm 0,003^{\mathrm{b}}$ & $0,216 \pm 0,076^{\mathrm{b}}$ \\
$\begin{array}{c}\text { Jagung } \\
\text { Tempurung }\end{array}$ & $0,041 \pm 0,005^{\mathrm{a}}$ & $0,116 \pm 0,011^{\mathrm{a}}$ \\
$\begin{array}{c}\text { Kelapa } \\
\text { Sekam Padi }\end{array}$ & $0,041 \pm 0,005^{\mathrm{a}}$ & $0,161 \pm 0,006^{\mathrm{a}}$ \\
\hline
\end{tabular}

Keterangan: Superscript berbeda pada kolom yang sama menunjukkan berbeda nyata $(\mathrm{p}<0,05)$

Berdasarkan penelitian ini, maka dapat diketahui bahwa perendaman asap cair (bonggol jagung, tempurung kelapa, dan sekam padi) dapat menurunkan kadar $\mathrm{Cd}$ $(\mathrm{p}<0,05)$ daging kerang hijau (Tabel 2). Kemampuan asap cair dalam mereduksi logam $\mathrm{Cd}$ disebabkan karena adanya asam asetat. $\mathrm{Cd}$ dalam kerang dapat bereaksi dengan asam asetat melalui perantara aquades untuk membentuk ikatan $\mathrm{Cd}$ dengan asam asetat [18].

Perlakuan perendaman asap cair dapat mereduksi kadar Cd sebesar 14,58\%. Jika dibandingkan dengan hasil penelitian Suprapti et al. [5], yaitu perendaman daging kerang hijau dalam asam asetat 25\% selama 90 menit dapat mereduksi logam Cd lebih besar, yaitu $37,88 \%$. Hal ini dipengaruhi total asam dalam asap cair lebih rendah, yaitu 10,75 s.d. 23,44 $\%$. Oustan et al. [19] menambahkan bahwa peningkatan konsentrasi asam organik dapat 
meningkatkan kemampuannya dalam mereduksi logam $\mathrm{Cd}$.

\section{Kadar Cu}

Tabel 2 menunjukkan bahwa perendaman asap cair (bonggol jagung, tempurung kelapa, dan sekam padi) dapat menurunkan kadar $\mathrm{Cu}(\mathrm{p}<0,05)$ daging kerang hijau sebesar 46,29\%. Kadar senyawa fenol, karbonil, dan asam dapat mempengaruhi daya khelasi atau kemampuan asap cair dalam mengikat dan mereduksi logam berat. Senyawa fenol, karbonil, dan asam dapat berikatan dengan logam berat membentuk kompleks $\mathrm{Pb}$-fenol, $\mathrm{Pb}$-karbonil, $\mathrm{Pb}$ karboksilat. Fenol memberikan efek paling besar terhadap penurunan kadar logam berat [6].

Logam berat dalam suatu bahan pangan dapat direduksi dengan menggunakan bahan pengkhelat di mana senyawa dari bahan pengkhelat akan mengikat logam berat. Bahan pengkhelat terlebih dahulu akan terdisosiasi menghasilkan ion, selanjutnya ion tersebut akan membentuk ikatan elektrostatik dengan logam berat [20]. Ikatan antara logam berat dengan bahan pengkhelat dapat dipengaruhi oleh $\mathrm{pH}$, banyaknya bahan pengkhelat, lama kontak, dan jenis bahan pengkhelat yang digunakan [21].

\section{Uji Koliform dan Total Bakteri}

Berdasarkan hasil pengujian koliform pada daging kerang hijau, seluruh sampel pada penelitian ini tidak mengandung bakteri bakterinya. Berdasarkan SNI No. 7388:2009, bahwa total bakteri maksimal yang diizinkan dalam daging kerang adalah $5 \times 10^{5} \mathrm{koloni} / \mathrm{g}$ [22].

Kemampuan asap cair dalam mereduksi bakteri dipengaruhi oleh jenis asap cair yang digunakan. Asap cair bonggol jagung mampu mereduksi bakteri sebesar $41,71 \%$, sedangkan asap cair dari tempurung kelapa adalah $50,57 \%$ dan asap cair dari sekam padi sebesar $34,57 \%$. Aktivitas antibakteri pada asap cair dipengaruhi oleh kandungan fenol dan asam. Zuraida et al. [8] menjelaskan bahwa fenol memiliki aktivitas antibakteri dengan cara koliform. Hal ini menunjukkan bahwa daging kerang hijau aman dikonsumsi. Keberadaan koliform mengindikasikan adanya bakteri yang bersifat patogen, sehingga pangan yang terkontaminasi dengan koliforn dapat menyebabkan penyakit jika dikonsumsi [23]. Bakteri koliform merupakan mikroorganisme yang menjadi indikator adanya pencemaran atau sanitasi yang tidak baik. Bakteri koliform termasuk dalam family Enterobacteriaceae yang merupakan bakteri indikator ada tidaknya pencemaran patogen. Semakin tinggi kandungan koliform dalam pangan, semakin berbahaya bagi kesehatan apabila pangan tersebut dikonsumsi [24]

Tabel 3. Total Koliform dan Bakteri pada Daging Kerang Hijau

\begin{tabular}{ccc}
\hline Perlakuan & $\begin{array}{c}\text { Total } \\
\text { Koliform } \\
(\mathrm{MPN} / \mathrm{g})\end{array}$ & $\begin{array}{c}\text { Total } \\
\text { Bakteri } \\
(\mathrm{koloni} / \mathrm{g})\end{array}$ \\
\hline Kontrol & negatif & $7,9 \times 10^{6}$ \\
$\begin{array}{c}\text { Bonggol } \\
\text { Jagung }\end{array}$ & negatif & $2,0 \times 10^{4}$ \\
$\begin{array}{c}\text { Tempurung } \\
\text { Kelapa }\end{array}$ & negatif & $3,6 \times 10^{4}$ \\
Sekam Padi & negatif & $1,0 \times 10^{4}$ \\
\hline
\end{tabular}

Tabel 3 juga menunjukkan bahwa perendaman asap cair dapat menurunkan total bakteri hingga ambang batas maksimum untuk memenuhi persyaratan keamanan pangan pada daging kerang. Sementara itu, daging kerang tanpa perendaman asap cair (kontrol) tidak memenuhi persyaratan keamanan pangan berdasarkan total

menghambat pertumbuhan bakteri. Fenol dapat menghambat akrivitas enzim dan merusak material genetik pada bakteri, serta meningkatkan permeabilitas membran sel.

Asam organik dapat berfungsi menghambat pertumbuhan bakteri dalam pangan. Prinsip penghambatan tersebut adalah senyawa asam menyebabkan penurunan $\mathrm{pH}$, sehingga fungsi fisiologis bakteri menjadi terganggu. Anionsenyawa asam mampu menembus membran sel bakteri, sehingga menyebabkan kerusakan sel [25] 
Tabel 4. Kadar Proksimat pada Daging Kerang Hijau

\begin{tabular}{ccccc}
\hline Perlakuan & $\begin{array}{c}\text { Kadar Air } \\
(\%)\end{array}$ & $\begin{array}{c}\text { Kadar Protein } \\
(\%)\end{array}$ & $\begin{array}{c}\text { Kadar Lemak } \\
(\%)\end{array}$ & $\begin{array}{c}\text { Kadar Abu } \\
(\%)\end{array}$ \\
\hline Kontrol & $78,47 \pm 0,81^{\mathrm{b}}$ & $16,34 \pm 0,19^{\mathrm{a}}$ & $0,33 \pm 0,17^{\mathrm{a}}$ & $3,11 \pm 0,42^{\mathrm{b}}$ \\
Bonggol Jagung & $77,30 \pm 1,38^{\mathrm{b}}$ & $16,90 \pm 0,27^{\mathrm{a}}$ & $0,46 \pm 0,36^{\mathrm{a}}$ & $1,35 \pm 0,28^{\mathrm{a}}$ \\
Tempurung Kelapa & $75,71 \pm 0,43^{\mathrm{a}}$ & $17,95 \pm 0,91^{\mathrm{b}}$ & $1,06 \pm 0,69^{\mathrm{a}}$ & $1,15 \pm 0,16^{\mathrm{a}}$ \\
Sekam Padi & $77,63 \pm 0,43^{\mathrm{b}}$ & $16,69 \pm 0,04^{\mathrm{a}}$ & $0,51 \pm 0,72^{\mathrm{a}}$ & $0,91 \pm 0,33^{\mathrm{a}}$ \\
\hline
\end{tabular}

Keterangan: Superscript berbeda pada kolom yang sama menunjukkan berbeda nyata $(\mathrm{p}<0,05)$

\section{Kadar Air}

Hasil pengujian proksimat (Tabel 4) mengindikasikan bahwa daging kerang dengan perendaman dalam asap cair tempurung kelapa memiliki kadar air yang lebih rendah dibandingkan kontrol $(\mathrm{p}<0,05)$. Kandungan air dalam pangan dapat mendukung pertumbuhan mikroorganisme. Penggunaan asap cair dapat menurunkan jumlah air pada suatu produk pangan karena adanya perbedaan tekanan osmosis. Dengan demikian, produk pangan memiliki umur simpan yang lebih lama [26].

Penurunan kadar air dalam daging kerang hijau disebabkan oleh senyawa fenol dalam asap cair. Hadanu dan Apituley [27] menyatakan bahwa setiap jenis asap cair memiliki senyawa fenol yang berbeda

\section{Kadar Protein}

Kadar protein pada daging kerang hijau dengan perlakuan perendaman asap cair tempurung kelapa lebih tinggi dibandingkan daging kerang hijau tanpa perlakuan (kontrol) dan dengan perlakuan asap cair (bonggol jagung dan sekam padi) (Tabel 4). Penambahan asap cair dalam suatu bahan dapat menyebabkan peningkatan kadar protein karena senyawa asam yang terkandung dalam asap cair menyebabkan terjadinya denaturasi dan koagulasi protein dalam pangan, sehingga protein bersifat tidak terlarut [29, 30].

Peningkatan kadar protein daging kerang yang direndam dalam asap cair tempurung kelapa juga berkorelasi dengan penurunan kadar air. Kadar air yang rendah menyebabkan kandungan protein akan meningkat per unit bobot bahan [31]. tergantung dari bahan bakar atau jenis kayu yang digunakan. Kadar fenol dalam asap cair berpengaruh terhadap kecepatan keluarnya air dari suatu bahan yang diberi perlakuan perendaman atau penambahan asap cair.

Penambahan asap cair tempurung kelapa menyebabkan chikuwa ikan nila memiliki kadar air lebih rendah dibandingkan chikuwa dengan penambahan asap cair jenis lain (batang serai dan bonggol jagung) [28].

Hal ini berkorelasi dengan kadar fenol masing-masing asap cair di mana asap cair tempurung kelapa memiliki kadar fenol tertinggi. Namun, hasil yang berbeda ditunjukkan pada daging kerang hijau, bahwa asap cair tempurung kelapa dengan kadar fenol terendah, menyebabkan penurunan jumlah air dalam daging kerang yang lebih besar.

\section{Kadar Lemak}

Hasil pengujian kadar lemak menunjukkan bahwa perendaman daging kerang dalam berbagai jenis asap cair tidak berpengaruh nyata $(\mathrm{p}>0,05)$ (Tabel 4). Asap cair mampu melindungi lemak pada bahan karena kandungan fenolnya yang memiliki aktivitas antioksidan. Senyawa fenol dalam asap cair dapat berfungsi sebagai antioksidan, yaitu menghambat oksidasi lemak dengan cara mendonorkan hidrogen [32]. Hasil penelitian yang sama juga ditunjukkan oleh Ernawati [33], yaitu perlakuan konsentrasi dan lama perendaman asap cair tidak mempengaruhi kadar lemak suatu produk pangan karena asap cair tidak dapat melarutkan lemak yang bersifat non polar. 
Tabel 5. Nilai Organoleptik Daging Kerang Hijau

\begin{tabular}{ccccc}
\hline Perlakuan & Kenampakan & Bau & Rasa & Tekstur \\
\hline Kontrol & $7,72 \pm 0,36^{\mathrm{a}}$ & $6,92 \pm 0,36^{\mathrm{a}}$ & $7,72 \pm 0,36^{\mathrm{b}}$ & $7,64 \pm 0,36^{\mathrm{a}}$ \\
Bonggol Jagung & $7,96 \pm 0,34^{\mathrm{a}}$ & $6,84 \pm 0,34^{\mathrm{a}}$ & $6,28 \pm 0,34^{\mathrm{a}}$ & $7,88 \pm 0,34^{\mathrm{a}}$ \\
Tempurung Kelapa & $8,20 \pm 0,26^{\mathrm{a}}$ & $6,76 \pm 0,26^{\mathrm{a}}$ & $6,41 \pm 0,26^{\mathrm{a}}$ & $8,12 \pm 0,26^{\mathrm{a}}$ \\
Sekam Padi & $7,48 \pm 0,55^{\mathrm{a}}$ & $6,60 \pm 0,55^{\mathrm{a}}$ & $5,72 \pm 0,55^{\mathrm{a}}$ & $7,46 \pm 0,55^{\mathrm{a}}$ \\
\hline
\end{tabular}

Keterangan: Superscript berbeda pada kolom yang sama menunjukkan berbeda nyata $(p<0,05)$

Kadar Abu

Penelitian ini menunjukkan bahwa perendaman daging kerang hijau dalam asap cair dapat menurunkan kadar abu daging. Penurunan ini berkorelasi positif terhadap penurunan kadar logam $\mathrm{Cd}$ dan $\mathrm{Cu}$. Kadar abu menunjukkan mineral yang terkandung dalam bahan. Ikan asap dapat mengandung mineral berupa kalsium, kalium, zinc, besi, dan magnesium serta logam berat yang berasal dari ikan dan bahan baku asap cair. Pangan mengandung air, protein, lemak, dan karbohidrat sebesar $96 \%$, sedangkan sisanya adalah mineral $[34,35]$.

\section{Organoleptik}

Berdasarkan data yang didapatkan dapat diketahui bahwa perendaman dalam asap cair menurunkan nilai organoleptik daging kerang hijau. Penurunan nilai organoleptik ditunjukkan terutama pada parameter rasa (Tabel 5), yaitu daging kerang yang direndam dalam asap cair memiliki rasa lebih asam dibandingkan kontrol $(p<0,05)$. Rasa khas yang diakibatkan asap cair dapat disebabkan oleh jenis dan jumlah fenol serta asam. Senyawa fenol berupa 4-methyl guaicol, 2,6dimethoxy phenol, dan guaicol berperan dalam pembentukan flavor khas asap [9, 36].

Perendaman daging kerang dalam asap cair tidak mempengaruhi nilai kenampakan, bau, dan tekstur (Tabel 5). Hal ini diduga karena penggunaan asap cair dalam konsentrasi yang rendah. Penggunaan asap cair dalam jumlah sedikit tidak akan mempengaruhi kenampakan (warna), bau, rasa, dan tekstur dari produk [37]. Warna produk dapat disebabkan oleh karbonil pada asap cair yang bereaksi dengan gugus amino pada produk, sedangkan senyawa fenol berkontribusi nyata terhadap aroma/bau dan tekstur produk yang diawetkan dengan pengasapan [38].

\section{KESIMPULAN}

Perendaman daging kerang hijau dalam asap cair dapat mereduksi logam berat $\mathrm{Cd}$ dan $\mathrm{Cu}$ serta total bakteri pada daging kerang hijau, tetapi perbedaan jenis asap cair yang digunakan (bonggol jagung, tempurung kelapa, dan sekam padi) tidak mempengaruhi kadar logam berat dan total bakteri.

Perbedaan jenis asap cair yang digunakan mempengaruhi kadar air dan kadar protein daging kerang hijau di mana perlakuan asap cair tempurung kelapa mampu menurunkan kadar air dan meningkatkan kadar protein daging kerang hijau. Perendaman dalam asap cair juga memberikan efek penurunan nilai organoleptik daging kerang hijau, yaitu menurunkan nilai rasa.

\section{UCAPAN TERIMAKASIH}

Penelitian ini didanai oleh Kementerian Riset, Teknologi, dan Pendidikan Tinggi melalui Program Kreativitas Mahasiswa Bidang Penelitian pada tahun 2019.

\section{DAFTAR PUSTAKA}

[1] M. Syah, R. M. S. Putri, dan G. Pratama, "Karakteristik vitamin dan mineral brunok (Paracaudina australis) dari Pantai Pelawan dan Tanjung Melolo Kabupaten Karimun Kepulauan Riau," Jurnal Marinade, vol. 2, no. 1, hal. 39-52, Apr 2019. 
[2] O. D. Uluozlu, M. Tuzen, D. Mendil, dan M. Soylak, "Trace metal content in nine species of fish from the Black and Aegean Seas Turkey," Food Chemistry, vol. 104, no. 2, hal. 835840, 2007

[3] N. O. W. Azalee, J. M. Jaheim, A. Rabu, A. M. A., Murad, F. D. A. Bakar, dan R. M. Illias, "Efficient removal of lignin with the maintenance of hemicellulose from kenaf by two-stage pretreatment process," Carbohydrate Polymers, vol. 99, hal. 447-453, 2014.

[4] J. Trcek, N. P. Mira, dan L. R. Jarboe, "Adaptation and tolerance of bacteria against acetic acid," Appl. Microbiol. Biotechnol., vol. 99, no. 15, hal. 621529, 2015.

[5] N. H. Suprapti, A. N. Bambang, F. Swastawati, dan R. A. Kurniasih, "Removal of heavy metals from a contaminated green mussel [Perna viridis (Linneaus, 1758)] using acetic acid as chelating agents," Aquatic Procedia, vol. 7, hal. 154-159, 2016.

[6] S. Hartati, P. Darmadji, dan Y. Pranoto, "Penggunaan asap cair tempurung kelapa untuk menurunkan kadar timbal $(\mathrm{Pb})$ pada biji kedelai (Glycine max)," Agritech, vol. 35, no. 3, hal. 331-339, 2015.

[7] F. Swastawati, Y. S. Darmanto, L. Sya'rani, K. R. Kuswanto, dan K. D. A. Taylor, "Quality characteristics of smoked skipjack (Katsuwonus pelamis) using different liquid smoke," International Journal of Bioscience, Biochemistry, and Bioinformatics, vol. 4, no. 2, hal. 94-99, 2014.

[8] I. Zuraida, Sukarno, dan S. Budijanto, "Antibacetrial activity of coconut shell liquid smoke (CS-LS) and its application on fish ball preservation," International Food Research Journal, vol. 18, hal. 405-410, 2011.
[9] S. Saloko, P. Darmadji, B. Setiaji, Y. Pranoto, dan A. K. Anal, "Antioxidative and antimicrobial activities of liquid smoke nanocapsules using chitosan and maltodextrin and its application on tuna fish preservation," Food Bioscience, vol. 7, hal. 71-79, 2014.

[10] T. Barki, N. Kristiningrum, E. Puspitasari, dan F. A. Fajrin, "Penetapan kadar fenol total dan pengujian aktivitas antioksidan minyak jahe gajah (Zingiber officinale var. officinale)," Jurnal Pustaka Kesehatan, vol. 5, no. 3, hal. 432-436, 2017.

[11] AOAC, "Association of Official Analytical Chemist Official Methods on Analysis," $18^{\text {th }}$ Ed, Gaithersburg, Maryland, 2005.

[12] A. T. Askar, M. U. K. Agung, Y. Andriani, dan L. P. Yuliadi, "Kelimpahan bakteri coliform pada air laut, sedimen dan foraminifera jenis Calcarina di ekosistem terumbu karang Pulau Pramuka, Kepulauan Seribu, DKI Jakarta," Jurnal Akuatika Indonesia, vol. 3, no. 1, hal. 36-41, 2018.

[13] Sukmawati dan F. Hardianti, "Analisis total plate count (TPC) mikroba pada ikan asin Kakap di Kota Sorong Papua Barat," Jurnal Biodjati, vol. 3, no. 1, hal. 72-78, 2018.

[14] B. D. Argo, Y. Sugiarto, dan A. B. Irianto, "Analisis kandungan abon ikan patin (Pangasius pangasius) dengan treatment alat "spinner pulling oil" sebagai pengentas minyak otomatis," Jurnal Keteknikan Pertanian Tropis dan Biosistem, vol. 6, no. 1, hal. 52-62, 2018.

[15] Badan Standardisasi Nasional [BSN], "SNI no. 01-2346-2006 tentang scoresheet organoleptik daging kerang beku," Badan Standarisasi Nasional, Jakarta, 2006. 
[16] Badan Standardisasi Nasional [BSN], "SNI no. 7387:2009 tentang batas maksimum cemaran logam berat dalam pangan," Badan Standarisasi Nasional, Jakarta, 2009.

[17] E. Wafaa, G. Saleh, dan M. Dief, "Some Studies on Heavy Metal Pollution in Water and Fishes," Egypt. J. Basic Appl. Physiol., vol. 2, no. 2, hal. 185-200, 2003.

[18] Mifbakhuddin., R. Astuti, dan A. Awaludin, "Pengaruh Perendaman Larutan Asam Cuka terhadap Kadar Logam Berat Cadmium pada Kerang Hijau," Jurnal Kesehatan, vol. 3, no. 1, hal. 14-20, 2010.

[19] S. Oustan, S. Heidari, M. R. Reyhanitabar, dan A. Bybordi, "Removal of heavy metals from a contaminated calcareous soil using oxalic and acetic acids as chelating agent," International Conference on Environment Science and Engineering, vol. 8, hal. 152-155, 2011.

[20] Q. Li, L. Chai, Q. Wang, Z. Yang, H. Yan, dan Y. Wang, "Fast esterification of spent grain for enhanced heavy metal ions adsorption," Bioresource Technology, vol. 101, hal. 3796-3799, 2010.

[21] B. A. Shaha, A. V. Shahb, B. N. Bhandaria, dan R. R. Bhatta, "Syinthesis, characterization and chelation ion-exchange studies of a resin copolymer derived from 8hydroxyquinoline-formaldehydecatechol," Journal of The Iranian Chemical Society, vol. 5, no. 2, hal. 252-261, 2008.

[22] Badan Standardisasi Nasional [BSN], "SNI no. 7388:2009 tentang batas maksimum cemaran mikroba dalam pangan," Badan Standarisasi Nasional, Jakarta, 2009.

[23] E. Suriaman dan W. P. Apriliasari, "Uji MPN coliform dan identifikasi fungi patogen pada air kolam renang di Kota
Malang," Jurnal Sain Health, vol. 1, no. 1, hal. 15-22, 2017.

[24] R. L. Puspitasari, D. Elfidasari, Y. S. Hidayat, F. D. Qoyyimah, dan Fatkhurokhim, "Deteksi bakteri pencemar lingkungan (coliform) pada ikan sapu-sapu asal Sungai Ciliwung," Jurnal Al-Azhar Indonesia Seri Sains dan Teknologi, vol. 4, no. 1, hal. 2427, 2017.

[25] S. S. Achmadi, N. R. Mubarik, R. Nursyamsi, dan P. Septiaji, "Characterization of redistilled liquid smoke of oil-palm shells and its aplication as fish preservatives," Journal Appl. Sci., vol. 13, no. 3, hal. 401-408, 2013.

[26] F. Swastawati, T. Surti, T. W. Agustini, dan P. H. Riyadi, "Karakteristik kualitas ikan asap yang diproses menggunakan metode dan jenis ikan berbeda," Jurnal Aplikasi Teknologi Pangan, vol. 2, no. 3, hal. 126-132, 2013.

[27] R. Hadanu dan D. A. N. Apituley, "Volatile compounds detected in coconut shell liquid smoke through pyrolysis at a fractioning temperature of 350-420 'C," Makara Journal of Science, vol. 20, no. 3, hal. 95-100, 2016.

[28] R. A. Leviyani, R. A. Kurniasih, dan F. Swastawati, "Application of liquid smoke for chikuwa tilapia," IOP Conference Series: Earth and Environmental Science, vol. 246, hal. $1-9,2019$.

[29] I. D. S. Budiarti, F. Swastawati, dan L. Rianingsih, "Pengaruh perbedaan lama perendaman dalam asap cair terhadap perubahan komposisi asam lemak dan kolesterol belut (Monopterus albus) asap," Jurnal Pengolahan dan Bioteknologi Hasil Perikanan, vol. 5, no. 1, hal. 125-135, 2016.

[30] M. Lasindrang, "Potential of liquid smoke from palm kernel shell as 
biopreservative to tuna (Thunnus sp.) fish protein," Indonesian Food and Nutrition Progress, vol. 14, no. 1, hal. 59-67, 2017.

[31] F. Swastawati, E. Susanto, B. Cahyono, dan W. A. Trilaksono, "Sensory evaluatian and chemical characteristics of smoked stingray (Dasyatis blekeery) processed by using two different liquid smoke," International Journal of Bioscience, Biochemistry, and Bioinformatics, vol. 2, no. 3, hal. 212216, 2012.

[32] I. K. Budaraga, Arnim, Y. Marlida, dan U. Bulanin, "Liquid smoke production quality from raw materials variation and different pyrolysis temperature," International Journal on Advance Science Engineering Information Technology, vol. 6, no. 3, hal. 306-315, 2016.

[33] Ernawati, "Pengaruh perlakuan asap cair terhadap sifat sensoris dan mikrostruktur sosis asap ikan lele dumbo (Clarias gariepinus)," Jurnal Kelautan, vol. 8, no. 2, hal. 52-59, 2015.

[34] M. K. E. Youssef, A. S. A. Gawad, B. M. Darwish, dan A. M. A. Hashem, "Assesment of the effect of liquid smoke on the chemical composition and quality attributes of fish balls during storage. Assiut J. Agric. Sci., vol. 46, no. 4, hal. 50-64, 2015.

[35] R. Hasanah dan I. Suyatna, "Karakteristik mutu produk ikan baung (Mystus nemurus) asap industri rumah tangga dari tiga Kecamatan Kutai barat, Kutai Kartanegara," Jurnal Akuatika, vol. 6, no. 2, hal. 170-176, 2015.

[36] V. Varlet, C. Knockaert, C. Prost, dan T. Serot, "Comparison of odor-active volatile compounds of fresh and smoked salmon," Journal of Agricultural and Food Chemistry, vol. 54, hal. 3391-3401, 2006.

[37] R. A. Kurniasih, P. Darmadji, dan Y. Pranoto, "Pemanfaatan asap cair terenkapsulasi maltodekstrin-kitosan sebagai pengawet ikan cakalang (Katsuwonus pelamis)," Jurnal Teknologi Hasil Pertanian, vol. 9, no. 1, hal. 9-16, 2016.

[38] S. Saloko, P. Darmadji, B. Setiaji, Y. Pranoto, dan A. K. Anal, "Encapsulation of coconut shell liquid smoke in chitosan-maltodextrin based nanoparticles," International Food Research Journal, vol. 20, no. 3, hal. 1269-1276, 2013. 